\title{
Colin Bingham, the Telegraph and poetic modernism in Brisbane between the wars
}

\author{
Patrick Buckridge \\ p.buckridge@griffith.edu.au
}

\begin{abstract}
Brisbane has sometimes been represented as a bulwark of literary traditionalism against the advances of poetic modernism in the southern capitals during the first half of the twentieth century. But as William Hatherell showed in The Third Metropolis, modernism had a brief but intense flourishing in the northern city during and immediately after World War II. This article traces the reception and practice of poetic modernism in Brisbane even earlier than that, in the period between the wars, both in the form of a vigorous critical debate over 'modernistic poetry' in the Courier-Mail and elsewhere, and also in the composition and publication of a significant quantity of self-consciously modernist poetry in Brisbane's evening daily, the Telegraph, with the active encouragement of the paper's literary editor, Colin Bingham, from 1930 to 1939.
\end{abstract}

If, as many cultural historians have argued, literary modernism is inseparable from big modern cities, ${ }^{1}$ then it would be unsurprising to find that Brisbane, the 'overgrown country town' of journalistic cliché, was not well-stocked with poets whose sense of alienation, despair, and social and psychological fragmentation was expressed in a style marked by violent discontinuities, multiple points of view, the flouting of traditional literary virtues like beauty and clarity, and an obscure allusiveness and obliquity. Sydney and Melbourne, one might surmise, would have been the only cities in which intensive urban modernity of the kind that engendered modernist art and literature in the great cities of Europe and America could have been experienced in Australia.

Yet, as William Hatherell has shown in his ground-breaking book, The Third Metropolis (2007), modernist poetry certainly flourished in Brisbane during World War II, participating enthusiastically in what Julian Croft identifies as the second, Surrealist-inspired wave of European and American modernism, distinguishable in time and character from the earlier 'classical' modernism of Ezra Pound, T.S. Eliot and W.B. Yeats. ${ }^{2}$ That wartime flourishing, energised in part by the friendly American 'occupation' of Brisbane after Pearl Harbor, centred on two new local journals: Meanjin Papers (later Meanjin), founded by Clem Christesen in Brisbane in 1940, and the short-lived Barjai (1943-47), a smaller, but more self-consciously 
experimental journal of the arts, mainly poetry, founded by a precocious group of senior secondary school students at Brisbane State High School, including Barrie (later Barrett) Reid and Laurence Collinson. ${ }^{3}$

A twenty-year-old Thea Astley was also involved with the Barjai group in the mid-1940s, and shared their avant-garde impulses in poetry - as, to a lesser extent, did Judith Wright, who read some of her earliest poems at Barjai meetings at the Lyceum Club. ${ }^{4}$ Even the thriving Catholic Readers and Writers Association, and its journal, View, made room for modernism in the 1940s. Its founder-editor, the poet Paul Grano, eventually sought to define a specifically Catholic modernism rooted in the work of Chesterton, Belloc and Gerard Manley Hopkins. But he also acknowledged and embraced the 'mark' of T.S. Eliot and Ezra Pound in the work of younger Catholic poets like Joseph O'Dwyer, whose long modernist poem, 'The Trojan Doom', won the C.J. Dennis Prize for poetry in $1941 . .^{5}$ The following arresting excerpt, from the last of its six cantos - undoubtedly modernist, but perhaps more 'first wave' than 'second wave' - was quoted by an unappreciative reviewer in the Courier-Mail. ${ }^{6}$

May it not happen that in the dark night, though the earth seem confident of her sombre power to hold one's feet, when the cocks crow dimly near and the cows, alone on a low wide plain, bassoon their urge, or the fleeting cars sprinkle their nervous trumpetings below, the soul may be released from labouring the pitiful prayer, and wholly take her charge into the unthreatened peace of contemplation? Steel to the magnet, the flung stone to earth, the planet to its star, star to its constellation, irresistibly is drawn. Why should the soul alone resist absorption into her source or suffer its resistance?

Hatherell locates early signs of the sudden and, as it turned out, fairly brief wartime flowering of cosmopolitan modernism in poetry and the visual arts in the Yearly Survey of Literature and Art in Queensland 1940, published towards the end of 1940 by the Queensland Association of Authors and Artists (QAAA), written by F.W. Robinson, the association's president, and Clem Christesen, its honorary secretary. The survey identified an emerging school of poets, three of whom Brian Vrepont, Paul Grano and James Picot - were already closely linked with Christesen in the Meanjin project, and at least one of whom - Vrepont - was a modernist or, as Robinson (a university English lecturer) saw it, 'perhaps the only link between the Romantic faith of our older writers and the very different enthusiasms of our undergraduates who take vers libre for granted and regard T.S. Eliot simply as a classic'. As Hatherell puts it, 'The foundations of the debate about the virtues of literary and artistic modernism, which would dominate Brisbane cultural life during the war years and beyond, were already present in 1940. ${ }^{7}$

In fact, that debate had commenced at least ten years earlier, and the purpose of this article is to assemble evidence of that earlier phase of modernism in Brisbane, to illustrate the ways in which modernist poetry was read and written, and to explore 
the terms and contexts in which the cultural controversy around modernism played out in the interwar decades. In that sense, the article is not so much contesting Hatherell's account as providing it with a 'prequel', one that helps to explain why, when the wartime flourishing occurred — sudden as it seemed — the ground was so well prepared.

On his interesting and valuable website, 'Old Queensland Poetry', Mark Carkeet argues that 'the first Queensland verse that might be described as experimental in nature' was published by the returned soldier Peter Austen (born Rudolf Augstein) in his second volume of poetry, The Young Gods, in $1919 .{ }^{8}$ Certainly some of the darker poems in this very dark collection have more than a hint of surrealism in expressing that sense of existential horror and imminent psychic breakdown that defines a certain branch of European modernism. There is, however, no evidence that Austen was directly influenced by, or aware of, the pre-war modernism of Pound and Eliot, or even of the later British war poets like Wilfred Owen, Siegfried Sassoon, Edmund Blunden and Edward Thomas. His main acknowledged influences were C.J. Dennis and Rupert Brooke! It is potentially confusing that Austen's only local literary affiliation before the war was with a small Brisbane magazine called The Modernist, for which he wrote a number of poems and reviews, but the title referred to religious, not artistic or literary modernism, and it was edited (and largely written) by Douglas Price, a defrocked Anglican cleric. ${ }^{9}$

More than a decade later, in 1932, Edgar Holt (1904-88) published what could be regarded as Queensland's first unambiguously modernist volume of poems. The lack of ambiguity is a measure of its direct debt to Eliot, whose name had become increasingly synonymous with modernist poetry since the publication of The Waste Land and Other Poems in 1922. Holt acknowledges the debt in the title, Lilacs from the Dead Land, a quotation from 'The Waste Land' itself, and most - though not all - of the poems in the volume, while technically skilful and at times genuinely evocative, are derivative of (perhaps one should say allusive to) specific poems by Eliot, notably 'Prufrock', 'Preludes' and 'Portrait of a Lady'. The excerpt below manages to almost quote all three, while at the same time conveying a sufficiently authentic mood of jaded bohemianism:

... Sleep like the morning tide rolls out

leaving me naked on a barren shore.

Sharply I hear a newsboy shout, and the baker's boy is knocking at the door.

Uncurls then Fiametta, smiles and yawns;

and through the window I can see

a smooth parade of square green lawns.

Asks Fiametta,

'Yes? An egg and tea!'

Flesh, face, and form are hers; a warmth is about her yet,

cooling as her laughter stirs

the sunlight on the coverlet.

Should I presume

to speak of orchids now, or tea,

or, lover still, assume

love's mutability?

At noon the trees leap into bud, 
drinking the sap insatiably;

and I exchange the lucid mood,

rejecting life in ennui.

What value has this high dispute

when buds proclaim the law of change

the single absolute? ${ }^{10}$

Serendipitously, my own recently acquired copy of Holt's book is inscribed by the author to Colin Bingham, a fellow poet and colleague at the Brisbane Telegraph, whose important role in fostering Brisbane poetry in the 1930s I shall presently discuss. Two years before the book appeared, Holt had left Brisbane for Melbourne to work on The Argus, and he never returned, thus following a trajectory common to so many Queensland writers for most of the twentieth century.

One poet who bucked the trend - at least for long enough to establish himself as one of the most prolific, and consistently experimental Brisbane poets of the interwar period - was 'Brian Vrepont' (Benjamin Truebridge). Vrepont was not consistently or derivatively modernist in Edgar Holt's style. A number of his poems — including one of his best known, 'The Apple Tree' — are simple, musical lyrics, hardly modernist by any definition; indeed, the anti-modernist literary editor of the Sydney Bulletin, Douglas Stewart, said of 'The Apple Tree' (which appeared on the first page of the first issue of Meanjin Papers) that it was 'perhaps the most beautiful lyric ever written in Australia'. ${ }^{11}$ Much of his output, however, is formally experimental, often violent, sometimes obscure in the use of language, expressing something of the alienation, despair and horror of the later modernist sensibility. Most of these qualities can be seen in the following lines from 'The Miracle', a long, sometimes impenetrable, but genuinely prophetic poem about the disaster of soil-erosion in the Australian countryside, which was awarded the C.J. Dennis Memorial Prize in 1939 (just two years before Joseph O'Dwyer won the same prize with 'The Trojan Doom'). The style of 'The Miracle', interestingly, has a greater affinity with the apocalyptic surrealism of the Angry Penguins generation than O'Dwyer's does:

A great fear rode the cities;

The paralysed streets jerked in spasm

Of news-boys' shrilling dead news,

Stones cast into a chasm;

Men sat vacant hours

And read of dust; priests prayed,

Church bells tortured the bone,

And traffic, indifferent to speed as hearses,

Listlessly strayed. ${ }^{12}$

Vrepont published a great many poems and reviews in numerous places from the early 1930s to the early 1950s: the Sydney Bulletin, Meanjin, and Angry Penguins, to name just a few. But the bulk of his poetry — some seventy poems in total ${ }^{13}$ was published in the Brisbane Telegraph through the decade of the 1930s, when Edgar Holt's friend Colin Bingham, also a friend of Vrepont's and an admirer of his work, was that paper's literary editor. ${ }^{14}$

Bingham played an important role in the reception of poetic modernism in Brisbane between the wars, and he did so in a context of considerable hostility in 
the literature columns of the Brisbane Courier (to 1933), later the Courier-Mail, the city's oldest and biggest daily newspaper. Through the 1920s, the Courier had tended to ignore recent and contemporary literature in favour of canonical English literature up to and including the late Victorians. Regular Saturday 'literary leaders', most of them written by J. Scott MacDonald, a local high school English teacher, and at least two substantial series of formal lectures on drama and the novel by 'Penfold Kyd' - probably a pseudonym for Professor J.J. Stable, of the University of Queensland - provided a more than respectable literary dimension to the paper without needing to engage with the looming modernist challenge to traditional literary culture. ${ }^{15}$

After 1930, however, the gloves came off. From the Courier-Mail's point of view, the enemy was at the gates, and could no longer safely be ignored. The main voice now raised against the modernists was that of the paper's long-time literary editor, Thomas Firmin McKinnon. McKinnon was a Scots-born journalist of the old school, a formidable literary scholar in his own right, and a mentor to many young Australian writers over the thirty years (1920-50) during which he wielded the power of editor, literary editor and chief reviewer for the paper. Evidently a gentle, likeable and dryly humorous man, ${ }^{16}$ he was nonetheless an unrepentant traditionalist, and his dislike for modernist poetry and its offshoots was both informed and genuine. In 1936 he focused his attack on Eliot - 'everywhere recognised as the leader of the modernistic school of poetry' - and more broadly (quoting a 'recent, ruffled anthologist') on the 'vociferous clique of literary snobs who grew like mushrooms in the ambiguous shade of TS Eliot's reputation' ${ }^{17}$ In McKinnon's cross-hairs, above all, is the gratuitous difficulty of Eliot's and others' poetry: ${ }^{18}$

If the reader of poetry complains that such poems [as The Waste Land] are difficult, the poet replies that they are meant to be difficult, and advises him to keep on cudgelling his brain until the intricate idea becomes plain to him. A few who like this kind of crossword puzzle do persist, but the pleasure such poetry gives to them is the exhilaration of unravelling a tangled skein, whether it be of cotton or twine or silk is of little consequence. But the vast majority of poetry lovers are alienated by these deliberate mystifications, being of the opinion - and a very excusable opinion - that verbal contortionists must have little to say when they are at such pains to say it obscurely. ${ }^{19}$

Invoking support from the chorus of academic ambivalence in the recently published university extension lectures by three Sydney Professors of English on Eliot, James Joyce and Edith Sitwell, ${ }^{20}$ he concludes by quoting, with dismay, Eliot's declaration that 'cheerfulness, optimism, and hopefulness stood for a great deal of what one hated in the 19 th century'. ${ }^{21}$

McKinnon nails his anti-modernist colours to the mast eloquently and at length at least once more in a review of Herbert Palmer's monograph, Post-Victorian Poetry (1938), described as:

a review of our poetry from Newbolt and Watson, Kipling and Bridges, down to T.S. Eliot of "The Waste Land" and the modernist groups in his train, ... so perplexing and obscure to their contemporaries that many a lover of verse has tossed them impatiently aside as a fungus on the tree of poetry or deliberate ringbarkers of the grove in the Garden of the Hesperides'. 


\section{He continues:}

The very large chapter on 'Modernism in Poetry' gives us perhaps the fullest exposition we have had of a movement which is indeed a revolt of the most violent kind, one which has flaunted itself so defiantly in the face of the public that it has turned away multitudes from poetry altogether. This is a pity, for modernism is only a single school or clique, of which other poets have been the fiercest critics. What confusion Futurism, Cubism, and Vorticism have wrought for painting the freak of modernism has done for poetry. To those inside the coterie these novelties are miracles of originality; to those outside the charmed circle they are for the most part incomprehensible fustian. Herbert Palmer traces this poetic frenzy back to the disordered genius of Marinetti, the showman and prophet of Futurism. Ezra Pound, too, introduced Imagism from America, a form of poetry that seizes on the tangible and visual, and avoids all emotion that would take the mind away from what can be clearly seen and grasped. Imagism lasted for ten years, and though a stunt it at least aimed at a clarity of image which later modernists dislike: The Sitwells further brought in a deliberate confusion of imagery and transformation of sense values. With them the sunlight 'hiccoughs,' the darkness 'grunts,' and the grasses 'quack.' Into the witches' cauldron of Modernist Poetry, Imagism and Sitwellism, Dadism [sic], Surrealism, and Despair have been thrown. 'The poetry of beauty is out of fashion,' exclaims one of the women satirists of this disintegration and sabotage of poetry. There have been strange things done in the name of poetry as of religion, but they pass away. The things that are lovely and of good report may be mocked and undergo temporary eclipse, but these attacks only win for beauty fresh lustre and new champions. ${ }^{22}$

McKinnon would have been reassured by the emergence of a new and powerful ally in the city, the recently appointed Anglican Archbishop of Brisbane, John Wand, an intellectually accomplished Oxford-educated theologian who undertook to write a weekly article for the Saturday Courier-Mail. This he did from a year or so after his arrival in late 1934 until his departure in 1943 to become Archbishop of Bath and Wells, and later Bishop of London. Wand's articles covered a range of moral, doctrinal, social and cultural topics, and among the latter was literary modernism, of which he disapproved almost as strongly as McKinnon, though for somewhat different reasons.

In one of his Saturday essays, 'Modernistic Literature', published just two weeks after McKinnon's first diatribe, Wand professes to have 'stumbled upon' a book called Aspects of Modernism, 'by a gentleman who rejoices in the attractive name of Janko Lavrin', and to have begun reading it under the mistaken impression (surely excusable in a bishop, hoho!) that it was about religious modernism, only to find he was reading about poetry! After this rather gauche opening gambit, the breadth, seriousness and sophistication of the essay can take one by surprise. It is true that its breadth of reference, at least, can be accounted for by the book itself - Lavrin, a Slovenian poet, critic, translator and historian, had been Professor of Slavonic Studies at the University of Nottingham since 1923, and had already published half a dozen critical monographs on European literature by 1935 (and would go on to publish a dozen more): he knew the field! ${ }^{23}$ But Wand's essay is not a review so much as a personal effort to understand, account for, and make a judgement on the worldwide cultural phenomenon of modernism that Lavrin had described in his basically psychoanalytic study; but to do it in Christian terms. 
Wand's focus, like Lavrin's, is less on the linguistic features of modernist writing - its 'difficulty' - than on the states of consciousness, or in his terms the spiritual condition, it reflects and expresses. Wand and Lavrin both see the common source of the 'various trends and groups' that comprise literary modernism as 'the romanticism which rejected the ... generalised values of the classicist literature, and stressed the importance of the individual, with all his own personal and subjective aims and emotions'. On this view, 'literary people ... during the last half-century ... have been led to measure all life by the standard of their own subjective feelings $\ldots$ at a time when they have lost all sense of certitude and authority in the world that is external to themselves'.

But - and this is a crucial qualifier - 'the self to which they have turned for refuge has proved anything but a tower of strength'. Indeed, 'the individual has found his own intellectual, emotional and volitional system blown to fragments. He can neither think, nor feel, nor will with certainty any more'. Many of Wand's formulations derive, reasonably enough, from Lavrin's book, as he works his way thoughtfully through its individuals, groups and categories: the Decadents, the Bombastic, the Tragic Failures. But at least one rather striking and effective analogy, between the modernist state of mind and the experience of a train journey, does not appear in Lavrin's book:

Travelling along in an express train I can contemplate with equanimity the apparent movement of the world outside the window; but if the seat upon which I sit, so far from remaining fixed, were to begin to gyrate with me, I should be subject to a vertigo which would make all consistent thought completely impossible. ${ }^{24}$

Wand also departs from Lavrin in discovering a way out of the crumbling prison of the modernist self: it is, of course, the way of faith, and he identifies it with the figure of Eliot (spelt 'Elliot'!). Apart from Oscar Wilde and D.H. Lawrence, Lavrin's book deals with French, Italian and Russian schools and writers only, with no mention of either Pound or Eliot (or Yeats, whom almost nobody except Edmund Wilson seems to have thought of as even a proto-modernist at this point in time). Of Eliot, Wand says:

Here and there a modern writer will find the principle of unity where it is always to be found, in the Author of all life. There at least is an example of a man who has felt to the full all the pathos and tragedy of our modern life, and had experienced all the difficulty of finding in it rhyme and reason. He has sunk to the depths, but he has risen again to the surface and finds himself with clear vision looking out upon a universe already bright with the promise of a new day. ${ }^{25}$

Eliot's conversion to Anglicanism in 1927 had been followed by two major religious poems - Ash Wednesday (1930) and Burnt Norton (1936) and two religious plays, The Rock (1934) and Murder in the Cathedral (1935) - by the time Wand's article appeared. Eliot - always the central poet of Anglo-American modernism - was thus, for the Archbishop, a powerfully redemptive figure, redeeming not only his own soul but potentially the whole modernist project. (By contrast, Brian Vrepont was to find betrayal and timidity in Eliot's 'turn', as he expressed it in the poem of angry disappointment he wrote about first reading Eliot's East Coker in 1940:

You who were not gazing from the window

But closeted with self, fearful of the view 
Too frankly pagan, you took affright,

Huddled in a corner, and whipped yourself

For loving so, in shock of doubt

Shuddered, and began telling the beads of fear. ${ }^{26}$

Wand's article provoked at least one letter in defence of the moderns, from R.A. Beven, quoting the British poet and anthologist Alida Monro's answer 'to those who believe that twentieth-century poetry is without faith or ideals' that new faith and new ideals may and will be built on the ruins of the old, and that 'the moderns of real worth, and they are many, have lost neither aim nor direction in thought or morality'. ${ }^{27}$ Hardly a full-blooded defence, but the Archbishop and the Courier-Mail together may have seemed to Beven an intimidating joint antagonist!

After McKinnon's swingeing attack on the British modernists two years later (quoted at length above), the asperity of the Courier's tone persisted: the 1938 issue of Galmahra, the university magazine, was ridiculed by 'Queenslander' (probably McKinnon himself) for the lack of music and meaning in its poetry, and for its typographical impertinence:

The editorial staff too seems to have developed some curious hostility to capital letters. They have not been permitted on the title pages. Modernist? Perhaps. If so, I feel grateful for not being a modernist. ${ }^{28}$

At the end of 1940, McKinnon started a review of a Jindyworobaks anthology, Corroboree to the Sun, edited by Ian Mudie, and the inaugural issue of Meanjin Papers, with the provocative observation, 'This is not an age of good poetry, and Australian poetry certainly should not be judged by that of 1940'. In fact, his main target throughout the review is the Mudie anthology, which he attacks for overblown rhetoric, abandoning punctuation and a lack of cheerfulness: 'too much struggle for effect, too much introspection, too little perspective'. His comments on Meanjin, by contrast, are largely favourable; he even singles out the poetic contributions of the four 'footprints' (Christesen, Grano, Picot and Vrepont) for praise for 'an enterprise that deserves encouragement'. ${ }^{29}$ His review of the second issue was even kinder, ${ }^{30}$ but none of this prevented Brian Vrepont from complaining and writing insulting poems about him in letters to Picot and Christesen. ${ }^{31}$

This, then, was the context of attitudes and arguments within which Colin Bingham's tenure as literary editor of the Brisbane Telegraph takes on its significance. From the late 1920s to the early 1940s, literary modernism was being treated with growing hostility by influential elements in the press, the church and the academy. The one consistent and reliable advocate, interpreter and supporter of literary modernism in Brisbane during this period was the Telegraph, and this was largely thanks to Bingham.

Bingham (1898-1986) was a poet and a career journalist. In 1920 he enrolled in a BA, and later a Diploma of Journalism, at the University of Queensland, where he associated with Jack Lindsay, Edgar Holt and P.R. Stephensen, among others, served as editor of Galmahra for two years (1923-24), won university medals for poetry on two occasions, and published two volumes of poetry, of which the first, Marcinelle and Other Verses (1925), was traditional and lyrical (and praised for these qualities by Professor Stable). ${ }^{32}$ The second, written under the influence of 
Edgar Holt with whom he published two issues of a little avant-garde magazine called the Merlin Papers, makes some mildly Eliotian experiments with free verse. ${ }^{33}$

In 1922, Bingham joined the staff of the Telegraph, where he wrote theatre and concert notes and leaders, and edited the Saturday literary page. In 1930, he became the paper's literary editor, ${ }^{34}$ but even before that, in the late 1920s, he had begun to reprint articles from elsewhere that discussed current trends in modern poetry in a helpful rather than defensive spirit. In December 1928, for example, the paper published a long article from the Christian Science Monitor entitled 'Modern Poetry: How to Enjoy It', by the American poet Jessica Nelson North, which explained the modernist impulse to shed the 'poetic trappings of a past age' to pursue forcefulness and pungency. Modern poets, she claimed, have 'learned to keep their metaphors unmixed, their images clear and concise, and to waste no words in padding lines to the correct number of syllables'. In this eminently balanced and reasonable overview of (mainly) American modernism, North acknowledges:

The amateur poetry-lover is often confused by the publicity and applause bestowed upon such writers as Ezra Pound, Hart Crane, Yvor Winters, E.E. Cummings, T.S. Eliot and others of their sort, whose writings seem to the average reader merely unintelligible mutterings. These more difficult and subtle poets write for an ultra-sophisticated minority, and it is no matter for despair if one cannot wholly understand them. In any of them, however, one may find great beauty of word-sounds without attempting to grasp the meaning. It is their dexterity with word-harmonies that has brought them their renown, and perhaps, though this is not necessarily universal, their profundity of thought. ${ }^{35}$

There is much more in this constructive vein, including some genuinely helpful hints on how to read individual poets aloud so as to bring out the best and most distinctive qualities of their poetry.

In his own Saturday 'literary leaders' through the first half of the 1930s, Bingham adopted a similarly balanced attitude to literary modernism both overseas and in Australia. While the Telegraph never came close to embracing its more provocative and challenging forms in the way some little magazines like Manuscripts in Melbourne and Thyrsus in Sydney did in the early 1930s (and of course Angry Penguins in the 1940s), he was nonetheless prepared to examine modernist experimentalism on its merits, to offer critical praise (and occasionally ridicule), as to individual poets and poems, but above all to try to inform and educate. In a lecture to the English Association, he is reported as saying that:

Modernistic poetry was extremely interesting, because if the core of value around which its extreme expression clustered could be found one would see there what contemporary thought and feeling were grafting into the great tree of poetic tradition. ${ }^{36}$

Defining modernism as 'insurgency' in the same lecture, he opined that 'its chief weakness was a failure to harmonise the musical, the pictorial and the intellectual', but that 'the modern poetry which could not be described as modernist was reflecting the beneficial influence of extremism', and that 'modernistic poetry was, in its nature, experimental, and to find against experiment on a general hearing of the case was to find against progress'. 
In a literary leader published just a month later, Bingham elaborated his complicated but ultimately accommodating attitude to modernism with a careful assessment of the merits of free verse, invoking Richard Aldington, Robert Graves and Laura Riding, and a comparison of contemporaneous recent poems by the ultramodernist Baroness Elsa von Freytag-Loringhoven and the traditional lyricist W.H. Davies (to the detriment of the former). He also quotes - as tantamount to poetry - the moving cri de coeur by Bartolomeo Vanzetti, the Italian-American anarchist, on the eve of his execution, with Nicola Sacco, by the State of Massachusetts in 1927.37

For Bingham, emotional sincerity remains the infallible sign of good poetry, and therefore the main charge against the modernists - it is Eliot, above all, he has in mind here - is that 'they have imposed upon contemporary literature a despairing intellectualism that must be rejected by anyone who recognises the source from which poetry has drawn its magic'. ${ }^{38}$ He found that magic in Davies, but he also found it in the poetry of John Shaw Neilson, to which he devoted a literary leader the following year, and which he felt represented a recovery of the precious 'naiveté' that had gone missing with modernism. ${ }^{39}$

In 1936, Bingham entered the fray once again, expressing his disquiet at the way in which modernism, for all its vigorous defiance of traditional norms of beauty and musicality, had made it easy for untalented poets to gain reputations by merely formulaic rejection of them. He quotes two lines by a youthful Dylan Thomas, than which, according to Edith Sitwell, 'nothing could convey more deeply and truly the wholeness of love'. The lines are:

She who was who I hold, the fats and flower,

Hell, wind and sea.

He compares them unfavourably with six lines of 'real poetry' by D.G. Rossetti on the same theme.

Bingham's central contention, here as elsewhere, is that there is a lot of modern poetry in Australia, including in the local scene, which engages with the modernity of its context without sacrificing the pleasures of beauty and musicality and the expression of universally human themes and emotions. There is, in other words, plenty of modern poetry that is not necessarily 'modernistic', and while the 'strange new things' done by the modernists have had their emancipatory and energising effects, the mainstream of modern poetry flows on in more recognisably 'poetic' forms. 'In Australia,' he claims, 'we have this significant circumstance that while we have not discovered many first-rate novelists we have men and women among us who are singularly gifted as makers of verse.' As an example of the latter, Bingham quotes the whole of a fairly conventional eighteen-line poem (untitled) by 'a Brisbane man' (unidentified), then supplies a very sympathetic and appreciative reading of the poem as 'a vivid picture of the reunion of two friends' whose relationship has 'lost its spontaneity, and principles that were formerly of great moment are become as inconsequential as autumn leaves. Alas! Such an experience is all too common. ${ }^{40}$

It comes as a slightly unwelcome surprise to discover that this praiseworthy poem reappeared in 1979 in a volume of poems written by none other than Colin Bingham! ${ }^{41}$ But the slight deception he perpetrated in 1936 did not change his central point, and it was perhaps no bad thing to have a poetry editor with a 
personal stake in redeeming the local reputation of modern poetry from popular perceptions of obscurity and intellectualism. He concluded his leader by proposing to reserve 'a special section for the weekly publication of selected verse'. The leader as a whole elicited a lively defence of the Thomas lines, to which Bingham responded with surprising asperity - perhaps because the writer also disparaged the poem by the anonymous 'Brisbane man' (that is, Bingham himself, incognito).

In any case, the 'special section' came into being five weeks later, and survived as 'Poems of the Week' until the end of 1939 - precisely the point at which Bingham was seconded to Australian Associated Press and left for London. As a singular 'Poem of the Week', however, the Telegraph kept the section going for another eight years. The first selection, in May 1936, comprised four poems: by Bingham himself (attributed), Alice Gore-Jones (a co-worker on the Telegraph), B.A. Shaw (unidentified, but perhaps blind) and Llywelyn Lucas, a frequent and long-term contributor - she had a poem in the section's last month of existence, December 1947 , as well as several dozen in the intervening years. Lucas, a strong-minded, independent and unconventional woman, lived in Brisbane for many years as the unmarried partner of the cartoonist Hal Eyre. Her poetry has some modernist leanings (occasional free verse), but her real talent - like that of Bingham himself, was for the descriptive and emotional lyric. ${ }^{42}$

Bingham's achievement was significant. In the early 1930s, through his literary leaders, he sustained an intelligent and well-informed engagement with the question of modernism in literature, especially poetry; and in the late 1930s - arising out of this engagement - he created and conducted a regular, inclusive space in Brisbane's second daily newspaper for local poetry. This space provided an outlet that, in purely quantitative terms, far exceeded that of any little magazine in Australia over a similar period: some 600 poems, and some thirty-odd poets, were published over the ten and a half years of the project. Some exhibited signs of an interest in modernist experiment with language and form but, generally speaking, the poems Bingham favoured seem to have been those that aspired to beauty, music and sincerity. It was to Bingham's credit, and to the advantage of Brisbane poetry in the interwar period, that he was able to reconcile a fairly strong antipathy to radicalmodernist experiments in poetic ugliness, dissonance and irony with a commitment to encouraging and disseminating a broader range of literary values than his own.

\section{Endnotes}

1 See, for example, Peter Nicholls, 'Modernism', in Roland Greene et al. (eds), Princeton encyclopedia of poetry and poetics, 4th ed. (Princeton: Princeton University Press, 2012), pp. 889-94.

2 Julian Croft, 'Responses to modernism', in Laurie Hergenhan (ed.), The Penguin new literary history of Australia (Ringwood: Penguin, 1988), p. 419.

3 William Hatherell, The third metropolis (Brisbane: University of Queensland Press, 2007), p. 69. For a fuller account of the 'Barjai' project, focused on Collinson's role, see William Hatherell, 'The Brisbane years of Laurence Collinson', Queensland Review 13(2) (2006), $1-12$.

4 Karen Lamb, Thea Astley: Inventing her own weather (Brisbane: University of Queensland Press, 2015), pp. 54-7. 
5 Paul L. Grano (ed.), Witness to the stars: An anthology of Australasian verse by Catholic poets (Sydney: Angus \& Robertson, 1946), 'Editor's Note', p. xii. Hatherell, The third metropolis, pp. 79-81.

6 'Brisbane man's prize poem', Courier-Mail (Brisbane), 24 September 1941, p. 4.

7 Hatherell, The third metropolis, pp. 40-1.

8 Old Queensland Poetry, http://www.oldqldpoetry.com/index.php.

9 Patrick Buckridge, 'Being elsewhere: Aesthetics, identities and alienation in Peter Austen's poetry', JASAL 5 (2006), 133-50.

10 Edgar Holt, Lilacs out of the dead land (Melbourne: Transition Press, 1932), pp. 25-6.

11 Patrick Buckridge and Belinda McKay (eds), By the book: A literary history of Queensland (Brisbane: University of Queensland Press, 2007), p. 50.

12 Brian Vrepont, Beyond the claw: poems (Sydney: Angus \& Robertson, 1943), p. 82.

13 Patrick Buckridge, 'Truebridge, Benjamin Arthur (1882-1955)', Australian dictionary of biography, (Canberra: National Centre of Biography, Australian National University, 2002), http://adb.anu.edu.au/biography/truebridge-benjamin-arthur-11883/text21277.

14 Chris Lawe Davies, 'Bingham, Colin William Hughie (1898-1986)', Australian dictionary of biography (Canberra: National Centre of Biography, Australian National University, 2007), http://adb.anu.edu.au/biography/bingham-colin-william-hughie-12211/text21895.

15 For J. Scott MacDonald, see Patrick Buckridge, 'Roles for writers', in Buckridge and McKay (eds), By the book, p. 48. The nine-lecture series on the history of English drama ran from July to October 1927; the six-part series, 'The Art of the Novel', ran through January and February 1930. Leigh Dale has suggested that the real author was Firmin McKinnon ("“Tinned literature": Literary discussion in the Brisbane Courier (1930)', Queensland Review 19(2) (2012), 190-204). I believe it was Stable: he was, after all, a lecturer in English at the time, and these articles seem very much like recycled university lectures. Furthermore, 'penfold' is a plausible double-synonym for 'stable'.

16 Desmond MacAulay, 'McKinnon, Thomas Firmin (1878-1953)', Australian dictionary of biography (Canberra: National Centre of Biography, Australian National University, 1986), http://adb.anu.edu.au/biography/mckinnon-thomas-firmin-7400/text12867.

17 The anthologist in question was Rodolphe Louis Mégroz, editor of $A$ treasury of modern poetry: An anthology of the last forty years (London: Isaac Pitman, 1936).

18 For an excellent recent account of the cultural debates about 'difficulty' in early twentiethcentury art and literature, see Leonard Diepeveen, The difficulties of modernism (New York: Routledge, 2003).

19 [Firmin McKinnon], 'The Waste Land and Hollow Men', Courier-Mail (Brisbane), 30 May 1936, p. 14.

20 A.J.A. Waldock, R.G. Howarth, E.J. Dobson, Some recent developments in English literature: A series of Sydney University extension lectures (Sydney: Sydney University Extension Board, 1935).

21 [McKinnon], 'Waste Land and Hollow Men', p. 14.

22 [Firmin McKinnon], 'Modernism in poetry', Courier-Mail (Brisbane), 30 July 1938, p. 4.

23 Rado L. Lencek, 'Janko Lavrin', http://www.journals.lib.washington.edu/index.php/ssj/ article/download/3608/3021.

24 Archbishop Wand, 'Modernistic literature: Tendencies revealed in critical essays', CourierMail, 13 June 1936, p. 21. The full text of the book under review, Janko Lavrin, Aspects of modernism: From Wilde to Pirandello (London: Stanley Nott, 1935), is available from http://www.archive.org. 
25 Wand, 'Modernistic literature', p. 21.

26 Brian Vrepont, 'In the company of T.S. Eliot', Telegraph (Brisbane), 24 August 1940, p. 6.

27 R.A. Beven, 'Modernistic literature', Courier-Mail (Brisbane), 17 June 1936, p. 27.

28 [Firmin McKinnon?], 'Brisbane Diary', Courier-Mail, 11 August 1938, p. 6.

29 Firmin McKinnon, 'Contemporary Australian verse', Courier-Mail, 28 December 1940, p. 7.

30 Firmin McKinnon, 'Australian poetry', Courier-Mail, 1 March 1941, p. 7.

31 Meanjin archive, Baillieu Library, University of Melbourne, box 1, folder 2, p. 1.

32 Mark Carkeet, 'Old Queensland Poetry', http://www.oldqldpoetry.com/index.php/colinbingham.

33 Carkeet, 'Old Queensland Poetry'.

34 Davies, 'Bingham'.

35 'Modern poetry. How it can be enjoyed. Hints by an American writer', Telegraph (Brisbane), 13 December 1928, p. 24.

36 'Modern poetry: Lecture by Mr Bingham', Telegraph (Brisbane), 17 October 1933, p. 16.

37 [Colin Bingham], 'Modern poetry', Telegraph (Brisbane), 18 November 1933, p. 8.

38 [Colin Bingham], 'Modern poetry', Telegraph (Brisbane), 18 November 1933, p. 8.

39 [Colin Bingham], 'The poetry of John Shaw Neilson', Telegraph (Brisbane), 16 June 1934, p. 9.

40 Colin Bingham, 'Modern poetry', Telegraph (Brisbane), 18 April 1936, p. 14.

41 Colin Bingham, National images and other poems (Sydney: Currawong Press, 1979), p. 40.

42 For more information on Gore-Jones and Lucas, and some examples of their work, see Carkeet, 'Old Queensland Poetry'. 